\title{
HUMANKIND AS BEING CREATED IN THE 'IMAGE OF GOD' IN THE OLD TESTAMENT: \\ POSSIBLE IMPLICATIONS FOR THE THEOLOGICAL DEBATE ON HUMAN DIGNITY
}

\author{
Hendrik Bosman \\ Old Testament \\ Stellenbosch University
}

\begin{abstract}
This contribution provides a survey of existing scholarship on the nature and extent of the 'image of God/imago Dei' according to the Old Testament. Some of the aspects that will be discussed are:

- Image in the physical sense with the focus on selem in Genesis 1 - humankind as representing the divine.

- Image in a spiritualized sense with the focus on demût in Genesis 1 - humankind as resembling the divine.

- Image as attribute or relationship - in conversation with Barth and Bonhoeffer.

A few concluding remarks will be made about human dignity and Old Testament anthropology as a theological synthesis between the Egyptian emphasis on humankind as a royal being and the Mesopotamian (Assyrian and Babylonian) view of humankind as a slave to do the most menial of work.
\end{abstract}

Key words: Human Dignity, Image of God, Old Testament

\section{Introduction}

The concept 'image of God' or 'imago Dei' forms part of Christian theology's view that humankind somehow corresponds to God as Creator, with a wide divergence of opinion as to what the correspondence entails (Merrill 2003:441-442).

One can ask with Annette Schellenberg (2009:97-98) to what extent the Old Testament (more in particular the Priestly author's) understanding of the imago Dei was influenced by the ancient Near Eastern perspectives on the relationship between humankind and the divine Creator.

In the four thousand year old Sumerian creation myth it is stated (Beyerlin 1978:77):

O my mother, the being who you named is there;

associate the image of the gods with him,

mix the nucleus of the clay above the primal ocean.

The gods and princely figures will thicken the clay,

But you must give life to the limbs.

The Akkadian cognate for selem is salmu; a term often used to refer to the statues of kings and dignitaries, as well as the images of deities (Merrill 2003:442). There are also a few 
examples where the Akkadian king is called a salmu ('Image') of a deity - Enuma Elish 1:15-16 (van Leeuwen 1997:644).

The four thousand year old Egyptian Instruction of Merikare depicts humans as the earthly representatives of the gods with the pharaoh as representative of humanity described as the bearer of the image of the sun god (Lichtheim 1973-1980):

Well tended is mankind - god's cattle

He made sky and earth for their sake,

He subdued the water monster,

He made breath for their noses to live.

They are his images, who came from his body,

He shines in the sky for their sake;

He made for them plants and cattle,

Fowl and fish to feed them.

Therefore it seems clear that Israel was surrounded by cultures where the image of the divine was an indication of royalty, a symbol of the power and authority of the king (Van Leeuwen 1997:644).

In Syro-Palestine, between the perennial superpowers to the North (Mesopotamia) and the South (Egypt), there are few references to humanity as the image of God. It is claimed that the bilingual Akkadian and Aramaic Tell Fekheriye inscription from the ninth century provides a reference to the king that contains an instruction that refers to the statue of a king and not to an image of a deity (Merrill 2003:442).

\section{Imago Dei in the Old Testament}

\section{Genesis 1:26-27}

The locus classicus for the Old Testament view of the imago Dei is Genesis 1: 26-27 where the word tselem is used three times and in each case translated with 'image' (LXX = eikon). Only once use is made of demût that is translated with likeness ( $\mathrm{XX}=$ homoiosis):

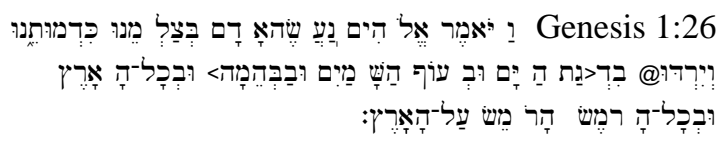

And God said: "Let us make man in our image, according to our likeness; and let them have dominion over the fish of the sea, and over the fowl of the air, and over the cattle, and over all the earth, and over every creeping thing that creepeth upon the earth."

The semantic field of the concept tselem has been rigorously debated for decades and Stendebach (2003:390-395) describes it as a pictorial representation or even a plastic replica that can refer to a dream image (Ps 73:20) or used as a technical term for divine images used in the cult (cast images of idols - Num 33:52; images of the Chaldeans on walls - Ez 23:14; statue of Nebuchadnezzar in Dan 2:31-35). Theologically more signifycant is the use of tselem to describe human beings as the tselem of God and two models are distinguished by Stendebach (2003:392-393):

- The first model assumes that humankind is created in the image of God (Elohim) and thereby commissioned to rule over the animal world (Gross, Hempel, Preuss, Scharbert, Schreiner, Steck, Wildberger and Zenger). 
- The second model differentiates between the creation of humankind and the creation of the world as belonging to two independent narratives, thereby emphasizing that the creation in the image of God establishes a special relationship between humanity and their Creator that did not apply to the world in general (Galling, Horst, Loretz, Maag, Rudolph, Westermann and Zimmerli).

Although demût is sometimes dismissed as a mere synonymous term for tselem, more attention should be given to its different nuances of meaning. According to Preuss (1978:257-258) it is significant that more than half of the occurrences of demût are found in the priestly and exilic literature of Ezekiel where it describes the glory of the Lord (1:5; $10: 1)$ or creatures that had the likeness of humans $(1: 26 ; 8: 2)$. There is no firm consensus that the combination of tselem and demût must be understood as a type of hendiadys where two terms combine to communicate the same idea, or that demût is a term that was added at a later stage to bring more ambiguity into the interpretation of the imago Dei. Jenni (1997:340-341), however, disagrees strongly from Schmidt and Westermann who argued that demût implies 'some diminished similarity' and as a counterargument he suggests that demût refers to 'total comparability'.

The formula 'let us make' is only used with regards to the creation of humankind, since the rest of creation came into being due to the command 'let there be...' (Gen 1:3, 6, 9, 11, 14, 29, 24). According to Sarna (1989:12) the use of the first person plural "evokes the image of a heavenly court in which God is surrounded by his angels" - resembling Van Rad's interpretation.

Other interpretations are even less convincing since the royal plural or plural of majesty is without parallel in the Old Testament and the plural of deliberation does not account for 3:22. God as Creator is here engaged in a "relationship of mutuality' ...human beings ... are created in the image of one who chooses to create in a way that shares power with others" (Fretheim 1994:345). Randall Otto (1992:505) reminded us that early Jewish exegesis interpreted the imago due to the first person plural as a reference to the divine familia ('household' or 'family' of God in heaven) - a variation on the theme of a possible Trinitarian allusion.

In verse 26 there is a clear connection between humankind's resemblance to God and sovereignty over the earth's resources. It is not clear whether humankind has power over nature as a result of being like God or whether that power constitutes the very essence of the similarity (Sarna 1989:12)

The nature of the 'image' and 'likeness' in verse 26 is closely related to the translation of the comparative particles 'be' ('in our image') and ' $k i$ '.('according to our likeness').

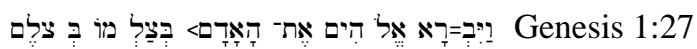

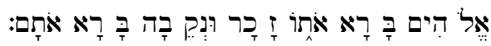

Genesis 1:27: And God created man in His own image, in the image of God created He him; male and female created He them.

In verse 27 only selem is used twice with the particle 'be'.

One could well ask: what the comparison entails suggested by the use of the particles ' $b e$ ' and to some extent ' $k i$ '?

- Do they imply that humans share with God some qualities such as personality, will and sensibility; but in a non-essential and more derivative way? Thus the imago Dei does not suggest equivalence between God and humankind but an analogous or corresponding relationship between humans and the divine. 
- It might also be that the imago Dei refers to humans being the image of God. Thus humankind does not share a certain reality with God but represents that reality.

- Most of the modern theological debate about the imago Dei oscillates between an ontological communality and a functional representation. The latter interpretation has strong grammatical grounds of the preposition ' $b e$ ' and is a 'beth' of identity ('beth essentiae').

At this point of the discussion one might well consider whether there is any significance in the fact that 'be' is used with 'tselem' and ' $k i$ ' with 'demût'?

\section{Genesis 5:1, 3}

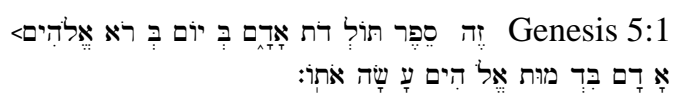

Genesis 5:1: This is the book of the generations of Adam. On the day that God created man, in the likeness of God made He him.

The word demût is used to relate Adam and all his descendants to God. Here 'be' is used with demût and not with tselem as in Genesis 1. Thus it becomes more likely that tselem and demût can be considered synonymous terms that both signify function and less so similitude (Merrill 2003:444).

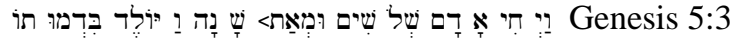

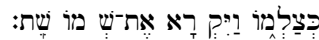

Genesis 5:3: And Adam lived a hundred and thirty years, and begot a son in his own likeness, after his image; and called his name Seth.

Both terms tselem and demût are used here to describe Seth as the son of Adam being created in his father's likeness and image - note the reverse word order in comparison with Genesis 1:26 that might be due to a 'stylistic trait of the author' (Van Leeuwen 1997:645). What constituted the image of God in Adam and Eve was transmitted through procreation to all future generations (Sarna 1989:42).

Genesis 9:6

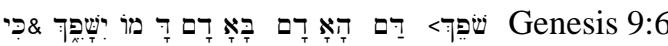

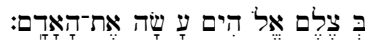

Genesis 9:6: Whoso sheddeth man’s blood, by man shall his blood be shed; for in the image of God made He man.

In the time after the Flood the shedding of blood must be avenged by the shedding of blood - avenging murder with capital punishment? - since humankind was made in the image of God. Murder is the supreme and capital crime because the dignity and sanctity of human life derive from the fact that every human being is made in the image of his God (Sarna 1989:62).

A chiastic construction in verse six formally makes the point that justice will involve the principle of measure for measure. The author links this rationale for his command with the fact that human beings have been made in the image of God - an understanding that still prevails in the post-flood world (Fretheim 1994:399). 
It now seems clear that all of humankind is created in the image of God and has a worth (dignity!) that is not destroyed by sin. Although the 'image of God' is only referred to in three Priestly sections of the Prologue of Genesis it might be possible to assume that it can be presupposed for all or most other Priestly texts in the Old Testament reflecting on the relationship between the Creator and humankind as creation (Van Leeuwen 1997:645).

\section{Sirach 17:1-7}

17 The Lord created human beings out of earth, and makes them return to it again.

${ }^{2}$ He gave them a fixed number of days, but granted them authority over everything on the earth.

${ }^{3}$ He endowed them with strength like his own, and made them in his own image.

${ }^{4} \mathrm{He}$ put the fear of them in all living beings, and gave them dominion over beasts and birds.

${ }^{6}$ Discretion and tongue and eyes, ears and a mind for thinking he gave them.

${ }^{7}$ He filled them with knowledge and understanding, and showed them good and evil.

Ben Sira understands the image of God to imply authority over the animals comparable to God's sovereignty in the heavens. The Greek concept of the five senses (sight, touch, smell, sound and taste), together with two additional faculties from Stoic philosophy (knowledge and reason) are reflected in this passage (NIB 5:730). Di Lella (1987:282) is of the opinion that "God made human beings in [his] own image ... the charter statement of human dignity and equality of all men, women and children in the sight of God."

In this Hellenistic reinterpretation of Genesis 1:26-27 the imago Dei becomes apparent in the dominion over animals, in the discretion possible in speech and sight, in a mind for thinking, knowledge and understanding; as well as being able to tell between good and evil. All this boils down to a divine likeness that results in human 'cognition and reflection' (Stendebach 2003:395).

\section{Wisdom of Solomon 2:21-24}

${ }^{21}$ Thus they reasoned, but they were led astray, for their wickedness blinded them,

22 and they did not know the secret purposes of God, nor hoped for the wages of holiness, nor discerned the prize for blameless souls;

${ }^{23}$ for God created us for incorruption, and made us in the image of his own eternity, ${ }^{24}$ but through the devil's envy death entered the world, and those who belong to his company experience it. 
In the conclusion to the Speech of the Wicked the reader is reminded that God destined human beings for 'incorruption'. To sustain this claim for immortality an appeal is made to the 'image of God' because God created human beings for immortality as we are made in the image of God 's 'identity' or 'eternity' - the Greek concepts are very close: idiotes for 'identity' and aidiotes for 'eternity' (NIB 5:464). Humans are not created immortal but for immortality. Human beings are created in the image of God and shape the original image into God's identity of immortality through their ethical conduct.

In early Judaism the notion of being created in the image of God became closely connected with wisdom. In Wisdom 7:25 wisdom becomes the mirror of divine activity and even an image of divine goodness - Sophia as the image of God! (Wildberger 1997:1084).

\section{In Conversation with Old Testament Theology}

Most Old Testament engagements with the imago Dei either attempt to be more precise in terms of philology, grammar and syntax (Barr et al), or be more extensive in terms of comparative linguistic investigations (Gross et al).

Some of the more important Old Testament suggestions with regards to the interpretation of the imago Dei can be summarized as follows:

- Hans Wildberger (1965) took note of Egyptian and Babylonian royal ideology as background for the understanding of the imago Dei. Thus the divine image implies that humankind must fulfill the role of God's representatives for acquiring domination of the earth.

- Walther Eichrodt (1967:122) argues that pre-Priestly traditions understood the image to be more physical, but then eventually the Priestly author developed a more spiritualized perspective.

- Gerhard von Rad (1973:144-146) is of the opinion that "the image of God in man contains no direct explanation about the form which specially constitutes it; its real point is rather the purpose for which the image was given to man ...his status as lord in the world". The image fundamentally means "the pattern on which [human beings are] fashioned is to be sought outside the sphere of the created."

- Claus Westermann (1974) suggests that the description of the creation of humankind was different from and independent of the description of creation as a whole.

- Werner Schmidt (1975) makes an appeal to distinguish between a Tatbericht (creation of humankind - the 'making' of humankind) and a Wortbericht (the rest of creation by means of the word 'let there be...').

- Graeme Auld (2005:259) considers Genesis 5:1-3 and 9:1-7 to be the source texts for 1:26-31 that were formulated to function as a new prologue to the book of Genesis that places humans further from animals and closer to the divine. This correlates well with the role of speech in Genesis 1-3 as shared by human and divine.

- Richard Middleton (2005) identifies three categories amongst scholars who have studied the image of God: substantialist, relational and functional or royal. According to him the syntax of Genesis 1:26 points to 'rule' as the purpose and not the consequence or result of the imago Dei. He concludes that Genesis 1 applied the imago Dei to all humanity rather than just to kings; it removes the idea that humanity was created to do the drudge work of minor gods and it affirms general human activity in the realms reserved for kings and gods. 
- Thomas Thompson (2009:135-148) identifies a three-fold allegory of humanity as created in the image of God as narrated in Genesis 1-11. Genesis 1:26 represents an idealistic presentation of the image according to which humankind functions as kings ruling over creation. According to Genesis 5:1-3 the emphasis is not on ruling as a king, but establishing a new relationship between a father and a son - Adam has a son who is created in his image and likeness. In conclusion one is confronted in 9:1-7 with human beings that are no longer peaceful rulers over creation but who are allowed to eat everything that moves, except meat with blood (Thompson 2009:148).

- Annette Schellenberg (2009:115) makes several important remarks: (a) The Priestly understanding of the imago goes beyond a functional focus on humankind as the lords over the animals. (b) The link between humans and God is not due to but despite who humans are. (c) The Old Testament places more emphasis on how God created humans in his image and less on humans being similar to God. (d) Since God is the Creator of all humankind, his image has implications for all humans and not only for a small royal elite.

For some time there seemed to be consensus that tselem denoted a concrete form of representation similar to the statue of a king. But with the advent of Priestly theology the second term demût was introduced to counter a lack of appreciation for God's transcendence by making the image more abstract and mysterious (Childs 1993:567-568).

\section{In Conversation with Systematic Theology: Barth and Bonhoeffer}

Amongst the Church Fathers the 'spiritual' understanding of the imago Dei was articulated by Tertullian who stressed free will as the most important characteristic ('signatus est') of the image of God in human beings. Augustine placed more emphasis on three aspects of the human soul that reflected a distant image of the Trinity: memory, intelligence and will (Dyrness 2008:43).

Protestant Reformers made good use of classical philology in their rigorous engagement with the Hebrew and Greek texts of the Bible. Thus the terms used for 'image' and 'likeness' were considered to be almost synonymous and their theological interpretation maintained a moral and spiritual trajectory. In the year of Calvin commemoration I would like to remind you of his opening paragraphs in the Institutes where he emphasizes the solidarity between the knowledge of God and the knowledge of ourselves. This theological - anthropology echoes Augustine in his Soliliquies (2.1): "That I may know myself; that I may know Thee."

\section{Karl Barth}

To understand the anthropology of Karl Barth one has to appreciate its foundation in his Christology: "to infer from His human nature the character of our own" (CD3/2:54).

Barth's discussion of Genesis 1:26-27 (CD 3/1), pays much attention to the plural ('let us make') and the clause ('male and female'). The gender (some suggest 'sexual') difference call all humans to a covenantal I - Thou relationship that is analogous to the Trinitarian I - Thou (echoes of Martin Buber!) [A proverb found in many African cultures, 'we are, therefore I am', might provide an interesting intertext with the Barthian anthropology?]

Despite the trouble Barth took to engage with Old Testament and Hebrew scholarship, his exegesis over-interprets the plural form of address in Genesis 1:26 and the repetition of the formula 'male and female' in Genesis 1:27. A more appreciative evaluation of Barth's 
exegesis of Genesis 1:26-28 was given by Nathan Macdonald (2008) who allows a "reading of imago as a relationship with God and the world analogous to Israel's election". A reading which he considers to be exegetically defensible and theologically suggestive.

The matter becomes theologically more complex when only Jesus Christ is seen as the image of God and that humankind can only access the imago Dei through Christ. This inevitably confronts us with the old conundrum of Barth's supposed Christological monism - does his Christological interpretation of the imago Dei do justice to the Old Testament text and context?

For me, Jüngel (1980:303) provides one of the more creative and theologically stimulating receptions of Barth by combining his relational understanding of the imago with the exegetically more acceptable lordship perspective: thus humankind "corresponds to this Lord as man with man in common lordship over the world." Many might not find this synthesis more palatable from an eco-theological view, but at least it attempts some synergy between competing dogmatic and exegetical points of view.

\section{Dietrich Bonhoeffer}

Not only Karl Barth (CD 3/1:83ff) but also Dietrich Bonhoeffer (1959:33-38) emphasize that the imago Dei is not a possession, or attribute but a relationship. Humankind's likeness to God lies in his capacity to be addressed as a 'thou' and to respond to the divine word (Childs 1993:568).

In one of his prison poems, Bonhoeffer (1998:38) asks 'Who am I?' - about one year before his execution. In the first three stanzas Bonhoeffer answers the question by means of how others (like his jailers) perceive him ('frankly, familiar and firm...'). His self understanding is less positive in the fourth stanza ('Troubled, homesick, ill, like a bird in a cage...'). The fifth stanza struggles with issues such as personal integrity and the tension between the positive understanding of others and his own self criticism ('In public a hypocrite and by myself, a contemptible, whining weakling?'). The last stanza reaches a climax and deserves to be quoted in full:

Who am I? Lonely questions mock me.

Who I really am, you know me, I am yours, o God!

[Wer ich auch bin, Du kennst mich, Dein bin ich, O Gott!

Bonhoeffer links to be known by God with belonging to God, which in a certain sense is related to image of God in Christ - only through Christ can we relate to God and to one another. Relationships that are crucial for self-understanding and for the theological foundation of human dignity.

\section{Conclusion}

In answering the question whether the Priestly understanding of the imago Dei was determined by the ANE context, I concur the four points made by Schellenberg (2009:111-112):

- The Priestly view of humanity presupposes that they are created in the image of God' not only with regard to "their function as God's deputies, but also with regard to their inherent nature." While the functional dimension of the divine image is emphasized in Genesis 1, a physical likeness between God and humans is reflected in Genesis 5 and 9. 
- Although the functional understanding is not in the foreground of the Priestly 'image of God' it is still there, without the emphasis it has in the ANE comprehendsions of images.

- A similar ambiguity exists with regards to the idea of a qualitative or physical likeness as foregrounded by the ANE - especially in Egyptian texts where the pharaoh has clear divine qualities.

- In stark distinction from the views in Egypt and Mesopotamia, the Priestly theological view advocated that not only royal individuals but all of humankind is related to God by means of the imago Dei - a so-called democratization of anthro-pology.

The predominance of the imago Dei in later (exilic and postexilic) Priestly texts might be explained by the pre-exilic preoccupation with idolatry. After the exile there was much less risk that the ambiguity inherent in die concept of the image of God could be construed in such a way that it kindled the dormant inclination towards the worship of divine images.

The mystery of human existence and the concomitant fragility of human dignity are sources for the wonder and bewilderment of biblical and theological scholars alike (Childs 1993:572). Perhaps the biggest contribution Biblical Studies can make to theological discourse in general is to remind readers of the Bible of the ambiguity of many texts (including the texts related to the imago Dei) and to resist glossing over the particularity of individual texts in service of coming to generalized (systematic?) conclusions about the whole of Scripture.

In conclusion, the image of God in every man and woman is a source of dignity and worth to all people. The imago Dei establishes a niche for humankind in creation that impacts on how we understand ourselves and interact with one another, as well as with the rest of creation.

To appreciate the textual warrant as well as the theological-ethical implications of the imago Dei, the dialogue between all theological disciplines, especially between Biblical Studies and Systematic Theology, must be nurtured and expanded - not always seeking consensus, but rigorously engaging the bones of contention and interrogating the points of disagreement. This theological Auseinandersetzung can further the cause of Theology to engage with academic disciplines outside of Theology and improve the quality of the theological discourse accessible to the faith community.

\section{BIBLIOGRAPHY}

Albright, CR 2001. “Complexity and the Imago Dei.” Currents in Theology and Mission 28:202-210.

Auld G 2005. “Imago Dei in Genesis: Speaking in the Image of God.” Expository Times 116:259-262.

Beisner, EC 1997. Imago Dei and the population debate, Trinity Journal 18:173-197.

Beyerlin, W et al 1978. Near Eastern Religious Texts relating to the Old Testament. Philadelphia:Westminster.

Bonhoeffer, D 1959. Creation and fall. London/New York.

Bonhoeffer, D 1998. The Prison Letters of Dietrich Bonhoeffer. Guildford: Eagle.

Childs, BS 1993. Biblical Theology of the Old and New Testaments. Theological reflection on the Christian Bible. Minneapolis: Fortress. 
Eichrodt, W 1985/1967/1964. Theology of the Old Testament Volume II. London: SCM.

Grenz, SJ 2002. "The social Gid and the relational self: toward a theology of the Imago Dei in Postmodern context”, Horizons in Biblical Theology 24:33-57.

Gross, W 2001. Gen 1,26.27; 9,6: Stature oder Ebenbild Gottes?, in Jahrbuch für Biblische Theologie Band 15. Neukirchen-Vluyn: Neukirchener Verlag, 11-38.

Houston, WJ 2007. "The character of YHWH and the ethics of the Old Testament: is Imitation Dei appropriate?” Journal of Theological Studies 58:1-25.

Janowski, B 2000. “Gottebenbildlichkeit I. Altes Testament und Judentum” in Religion in Geschichte und Gegenwart Band 3 F-H (4. Auflage). Tübingen: Mohr Siebeck, 1159-1160.

Jenni, E 1997. “dmh to be like”, in E Jenni \& C Westermann (eds.), Theological Lexicon of the Old Testament Volume 1. Peabody: Hendrickson, 339-342.

Johnston, GH 2008. “Genesis 1 and Ancient Egyptian creation myths.” Bibliotheca Sacra 165:178-194.

Jüngel, E 1980. “Der Gott entsprechende Mensch,: in Entsprechungen: Gott - Wahrheit Mensch. München: Kaiser.

Kaiser, WC Jr. 1979. Toward an Old Testament Theology. Grand Rapids: Eerdmans.

Lichtheim, M 1973-1980. Ancient Egyptian Literature 3 vols. Berkeley: University of California.

Macdonald, N 2008. "The Imago Dei and election: reading Genesis 1:26-28 and Old Testament scholarship with Karl Barth.” International Journal of Systematic Theology 10:303-327.

Merrill, EH 2003. “Image of God”, in TD Alexander \& DW Baker (eds.) Dictionary of the Old Testament: Pentateuch. Downers Grove: InterVarsity Press, 441-445.

Middleton, JR 2005. The liberating image: the ‘Imago Dei’ in Genesis 1. Grand Rapids: Brazos.

Neumann - Gorsolke, U 2001. "Mit Ehre und Hoheit hast Du ihn gekrönt” (Ps 8,6b), in Jahrbuch für Biblische Theologie Band 15. Neukirchen-Vluyn: Neukirchener Verlag, 39-65.

Otto, RE 1992. “The Imago Dei as Familitas.” JETS 35:503-513.

Preuss, HD 1978. "damah / demûth”, in GJ Botterweck \& H Ringgren (eds.), Theological Dictionary of the Old Testament Volume III. Grand Rapids: Eerdmans, 250-260.

Rosner, BS 2005. “Known by God: CS Lewis and Dietrich Bonhoeffer.” Evangelical Quarterly 77:343-352.

Schellenberger, A 2009. "Humankind as the 'image of God'. On the Priestly predication (Gen 1:26-27; 5:1; 9:6) and its relationship to the ancient Near Eastern understanding of images.” Theologische Zeitschrift 65:97-115.

Stendebach, FJ 2003. "tselem", in GJ Botterweck \& H Ringgren (eds.), Theological Dictionary of the Old Testament Volume III. Grand Rapids: Eerdmans, 386-396.

Thompson, TL 2009. “Imago Dei. A problem in Pentateuchal discourse.” Scandinavian Journal of the Old Testament 23:135-148.

Van Leeuwen, RC 1997. “Form, Image”, in WA VanGemeren (ed.), New International Dictionary of Old Testament Theology and Exegesis Volume 4. Grand Rapids: Zondervan, 643-648. 
Von Dehsen, CD 1997. “The Imago Dei in Genesis 1:26-27.“ Lutheran Quarterly 11:259-270.

Von Rad, G 1973. Old Testament Theology Volume 1. Edinburgh: Oliver \& Boyd.

Vriezen, TC 1970/1949. An outline of Old Testament Theology (2nd ed.). Oxford: Blackwell.

Wildberger, H 1997. “tselem” image”, in E Jenni \& C Westermann (eds.), Theological Lexicon of the Old Testament Volume 3. Peabody: Hendrickson, 1080-1085.

Zimmerli, W 1978. Old Testament Theology in outline. Edinburgh: T\&T Clark. 